\title{
Variation in proximate composition and fatty acid profiles of mud crab meat with regard to sex and body parts
}

\author{
K. R. SREELAKSHMI, L. MANJUSHA, V. R. VARTAK* AND G. VENKATESHWARLU \\ ICAR-Central Institute of Fisheries Education, Seven bunglows, Versova, Mumbai - 400 061, Maharashtra, India \\ "Khar Land Research Station, Dr. Balasaheb Sawant Konkan Krishi Vidyapeeth, Bandar Road, Panvel - 410206 \\ Raigad, India \\ e-mail: manjusha@cife.edu.in
}

\begin{abstract}
Mud crabs are the most widely distributed and cultured group among portunid crabs. The meat yield, proximate composition and fatty acid profile of two species of mud crabs Scylla serrata and Scylla tranquebarica were compared with respect to gender and different body parts and the results showed significant differences $(p<0.05)$ in biochemical composition. Meat yield was higher in males, whereas females had higher protein content. The lowest moisture content $(78.5 \%)$ was in the female body meat of both the species and the highest $(83.85 \%)$ in male claw meat of $S$. serrata. Health beneficial polyunsaturated fatty acids (PUFA) content was found in the range of 28.81-42.66\% with a higher $\mathrm{n} 3$ to $\mathrm{n} 6$ PUFA ratio of 1.34-5.28. Principal component analysis (PCA) revealed higher $\mathrm{n} 3$ PUFA content in the claw meat of S. tranquebarica and body meat of $S$. serrata. The results throw light on the possibilities for both farmers as well as processors to judiciously select the species, gender and the meat source based on their compositional features in order to cater specifically to the market requirements.
\end{abstract}

Keywords: Body meat, Claw meat, Fatty acids, Gender, Mud crab, Polyunsaturated fatty acids

Crustaceans are of great commercial and nutritional importance to humans. Among the edible marine crustaceans, crabs rank third after shrimps and lobsters by virtue of their importance as a favoured delicacy and the value of fishery they support (Balange et al., 2003). Crabs are much in demand as a delicacy and as a quality food, due to their size, meat content and unique flavour (Rattanachote and Dangwatanakul, 1992) and hence command high prices in domestic and international markets. Mud crabs of the genus Scylla are a common component of the brackishwater fauna. Scylla serrata (Forsskal, 1755) is the most widely distributed species, followed by Scylla tranquebarica (Fabricius, 1798). The global landing of crabs is recorded as 13, 43,823 t (FAO, 2011). The total landing of crabs in India comes to the tune of 50,847 $\mathrm{t}$ (CMFRI, 2011), with major contribution from mud crabs. Shellfish vary widely in their nutrient content as indicated by the differences in contents of moisture, fat, ash, protein and various volatile compounds in meat depending on the gender and body parts of blue crab, Callinectes sapidus and in the south-east Asian crab, Charybdis feriatus (Chung, 1999; Lee et al., 1993). Crabs differ in their market value based on the gender variations and size as well. There is an increased preference for gravid females as compared to immature females and males in seafood restaurants across Asian countries. Hence they command higher prices too. Besides, large sized hard-shelled crabs fetch high rate
(5-6 times) compared to soft crabs. The specific nutritional characteristics of mud crabs with respect to differences in gender and body parts have not been studied adequately. The biochemical composition and nutritional value should be known to facilitate the farming/fattening, processing, utilisation, and marketing of value-added crab products for human consumption. Hence the present study was taken up with the purpose of determining the meat yield, proximate composition and fatty acid profile of body and claw meats of $S$. serrata and $S$. tranquebarica with respect to gender variations.

Live mud crabs of wild origin were bought from the local fish market, Four bungalows, Mumbai, India. The standard carapace width of the crabs measured was in the range of $100-130 \mathrm{~mm}$ with mean weight of 200-300 g. The claws, outer shell, gills and appendages were removed and washed thoroughly in chilled water, followed by meat removal. The moisture content was analysed using automatic moisture analyser (Denver, IR 120). The crude protein (estimation of total nitrogen by Kjeldahl method), crude lipid (Soxhlet extraction method) and ash contents were analysed according to the AOAC procedures (AOAC, 2000). The total lipid was extracted following the method of Folch (1957) and the lipid extract was converted to fatty acid methyl ester (FAME) according to AOAC (2000). The FAME was analysed 
in a Shimadzu QP 2010 quadrupole mass spectrometer connected to a GC 8060 gas chromatograph equipped with a Carbowax $(25 \mathrm{~m} \times 0.25 \mathrm{~mm} ; 0.25 \mu \mathrm{m}$ film thickness $)$ column (Cromlab S. A.). The SPSS statistical package (version 16.1) was used for statistical analysis of results. Principal component analysis (PCA) was also done using Unscrambler (CAMO, version 9.7, USA) software.

Regardless of the species, males had a higher meat yield both from body and claws, with $32.99 \%$ in $S$. tranquebarica followed by $30.44 \%$ in $S$. serrata (Table 1). Similar meat yields of about $32 \%$ were reported for both males and females of blue swimmer crab Portunus pelagicus by $\mathrm{Wu}$ et al. (2010). However, both the species of mud crabs in the present study showed higher meat yield than other crab species such as the Chinese mitten crab Eriocheir sinensis with 24.2\% (Chen et al. 2007), the deep water crab Charybdis smithii with 15.3\% (Balasubramanian and Susheelan, 2001), Atlantic spider crab Maja brachydactyla with 17\% (Marques et al., 2010) and brown crab Cancer pagurus with about 23\% (Barrento et al., 2010).

The proximate composition of crab meat is shown in Table 2. Protein content was highest (17.63\%) in body meat and lowest (11.19\%) in claw meat of $S$. tranquebarica. In contrast with the meat yield data, the meat from female crabs had significantly higher $(\mathrm{p}<0.05)$ protein content than males irrespective of species and body parts variation. This is in agreement with the results of Zafar et al. (2004) who reported a high protein content of female $S$. serrata. Similar reports were given by Khan (1992) who recorded

Table 1. Meat yield ( $\%$ of total body weight) from different body parts of Scylla spp.

\begin{tabular}{lllll}
\hline Species & Gender & Body meat & Claw meat & Total \\
\hline S. serrata & Male & $13.64 \pm 0.6^{\mathrm{a}}$ & $16.8 \pm 0.6^{\mathrm{c}}$ & $30.44 \pm 0.6^{\mathrm{c}}$ \\
& Female & $17.12 \pm 0.5^{\mathrm{b}}$ & $11.43 \pm 0.2^{\mathrm{a}}$ & $28.55 \pm 0.3^{\mathrm{b}}$ \\
S. & Male & $19.1 \pm 0.4^{\mathrm{c}}$ & $13.8 \pm 0.8^{\mathrm{b}}$ & $32.9 \pm 0.4^{\mathrm{d}}$ \\
tranquebarica & Female & $16.2 \pm 0.5^{\mathrm{b}}$ & $11.4 \pm 0.3^{\mathrm{a}}$ & $27.6 \pm 0.2^{\mathrm{a}}$ \\
\hline
\end{tabular}

Values represent mean $\pm \mathrm{SD}$ on wet weight basis $(n=3)$. Different superscripts within a column denote significant differences $(\mathrm{p}<0.05)$
$11.60 \%$ protein for male and $19.92 \%$ protein for female of S. serrata. Chinnamma and Gopakumar (1987) reported 16.80 and $16.28 \%$ protein in body meat and claw meat of S. serrata. The moisture content was found to be higher in male claw meat. The lowest moisture content (78.5\%) was found in the meat from females of both species and the highest $(83.85 \%)$ in claw meat of male $S$. serrata. Zafar et al. (2004) reported a moisture content of $83.5-76.5 \%$ in males and $79.5-74.98 \%$ in females of $S$. serrata. A mean moisture content of $78.8 \%$ was observed by $\mathrm{Wu}$ et al. (2010) in blue swimmer crab. The highest ash content was in claw meat $(2.6 \%)$ of both species and the lowest in body meat (1.61\%) of male $S$. tranquebarica. The mean ash content varied from 1.8 to $2.66 \%$ in $S$. serrata and 1.61 to $2.63 \%$ in $S$. tranquebarica. Zafar et al. (2004) reported an ash content of $1.2-2.22 \%$ in males and $1.62-2.34 \%$ in females of $S$. serrata.

The meat from female crabs had a significantly higher $(p<0.05)$ fat content compared to male crabs. Similar results have been reported by $\mathrm{Wu}$ et al. (2010) in blue swimmer crabs. Also, the claw meat was found to be fattier than body meat in males and females of both species. Fat content varied from 0.53 to $1.54 \%$ in S. serrata and 0.65 to $1.37 \%$ in $S$. tranquebarica, which are higher than those reported for Atlantic spider crab $(0.32 \%)$ by Marques et al. (2010), brown crab $(0.3 \%)$ by Barrento et al. (2010) and Chinese mitten crab (0.9\%) by Chen et al. (2007). Yearly average fat content of $0.51 \pm 0.12 \%$ in males and $0.62 \pm 0.13 \%$ in females of S. Serrata was reported by Zafar et al. (2004). The nutritive value of crabs is primarily determined by lipids and particularly n-3 poly unsaturated fatty acids (PUFA) (Latyshev et al., 2009). Fatty acid composition of body and claw meats of male and female $S$. serrata and S. tranquebarica are presented in Table 3. The highest PUFA content $(42.66 \%)$ was recorded from the claw meat of female $S$. tranquebarica and the highest n-3 PUFA content (34.49\%) from the claw meat of male S. tranquebarica. Ratio of n-3 to n-6 PUFA has been used as an index for fatty acid nutrition and a higher ratio normally indicates a high nutritional value (Chen

Table 2. Proximate composition of mud crab meat ( $\%$ of wet weight)

\begin{tabular}{lllllll}
\hline Species & Gender & Meat & Crude protein (\%) & Moisture (\%) & Ash (\%) & Crude fat (\%) \\
\hline S. serrata & Male & Body & $12.22 \pm 1.23^{\mathrm{b}}$ & $81.67 \pm 1.33^{\mathrm{ab}}$ & $1.8 \pm 0.23^{\mathrm{ab}}$ & $0.53 \pm 0.06^{\mathrm{a}}$ \\
& & Claw & $10.27 \pm 0.9^{\mathrm{a}}$ & $83.85 \pm 0.68^{\mathrm{b}}$ & $2.66 \pm 0.59^{\mathrm{e}}$ & $0.68 \pm 0.02^{\mathrm{bc}}$ \\
& Female & Body & $16.42 \pm 1.15^{\mathrm{d}}$ & $78.51 \pm 1.46^{\mathrm{a}}$ & $2.51 \pm 0.13^{\mathrm{de}}$ & $1.26 \pm 0.01^{\mathrm{c}}$ \\
S. tranquebarica & & Claw & $15.23 \pm 1.53^{\mathrm{cd}}$ & $80.12 \pm 1.24^{\mathrm{ab}}$ & $1.84 \pm 0.08^{\mathrm{ab}}$ & $1.54 \pm 0.07^{\mathrm{b}}$ \\
& Male & Body & $15.63 \pm 0.04^{\mathrm{cd}}$ & $81.49 \pm 3.64^{\mathrm{ab}}$ & $1.61 \pm 0.02^{\mathrm{a}}$ & $0.65 \pm 0.00^{\mathrm{b}}$ \\
& & Claw & $14.03 \pm 3.43^{\mathrm{c}}$ & $82.4 \pm 0.96^{\mathrm{ab}}$ & $2.63 \pm 0.11^{\mathrm{e}}$ & $0.71 \pm 0.01^{\mathrm{c}}$ \\
& Female & Body & $17.63 \pm 0.89^{\mathrm{de}}$ & $78.63 \pm 2.7^{\mathrm{a}}$ & $2.04 \pm 0.12^{\mathrm{bc}}$ & $1.23 \pm 0.04^{\mathrm{d}}$ \\
& & Claw & $11.19 \pm 0.19^{\mathrm{ab}}$ & $81.27 \pm 2.95^{\mathrm{ab}}$ & $2.21 \pm 0.12^{\mathrm{cd}}$ & $1.37 \pm 0.09^{\mathrm{d}}$ \\
\hline
\end{tabular}

Values represent mean \pm SD on wet weight basis $(n=3)$. Different superscripts within a column denote significant differences $(\mathrm{p}<0.05)$ 
Table 3. Fatty acid composition (\% of total fatty acids) of mud crab meat

\begin{tabular}{lllllllll}
\hline Fatty acid & ${ }^{a} S^{\mathrm{c} M B}$ & $\mathrm{SS}^{\mathrm{d}} \mathrm{MC}$ & $\mathrm{SS}^{\mathrm{e} F B}$ & $\mathrm{SS}^{\mathrm{f} F C}$ & ${ }^{\mathrm{b} S T M B}$ & STMC & STFB & STFC \\
\hline $12: 0$ & 1.34 & 3.49 & 0.99 & 0.33 & 0.89 & 1.21 & 0.71 & 0.78 \\
$14: 0$ & 1.96 & 1.63 & 2.44 & 3.15 & 3.7 & 1.46 & 2.72 & 1.8 \\
$15: 0$ & 1.03 & 1.32 & 0.88 & 0.72 & 2.41 & 1.5 & 1.55 & -- \\
$16: 0$ & 21.13 & 29.82 & 25.46 & 26.07 & 25.17 & 17.06 & 25.83 & 19.35 \\
$17: 0$ & 1.38 & -- & 1.62 & 3.08 & 3.88 & -- & 2.22 & 1.46 \\
$18: 0$ & 14.6 & 12.75 & 5.98 & 15.45 & 11.98 & 9.46 & 12.95 & 11.48 \\
$16: 1, \mathrm{n} 7$ & 2.07 & -- & 3.35 & 5.29 & 7.22 & 7.06 & 5.24 & 5.19 \\
$18: 1, \mathrm{n} 9$ & 15.72 & 19.52 & 15.65 & 16.02 & 9.79 & 10.08 & 15.81 & 14.29 \\
$18: 2, \mathrm{n} 6$ & 3.14 & -- & 1.1 & 4.51 & 3.44 & - & 4.31 & 4.56 \\
$20: 2, \mathrm{n} 6$ & 1.77 & 0.59 & 2.2 & 0.46 & 0.99 & 1.93 & 1.64 & 0.72 \\
$20: 4, \mathrm{n} 6$ & 5.42 & 5.97 & 1.98 & 7.34 & 5.17 & 6.1 & 5.14 & 6.81 \\
$20: 5, \mathrm{n} 3$ & 19.03 & 14.9 & 14.63 & 13.25 & 12.95 & 21.31 & 11.57 & 18.57 \\
$22: 6, \mathrm{n} 3$ & 12.76 & 8.56 & 12.29 & 3.25 & 9.59 & 13.18 & 7.67 & 12 \\
SAFA & 41.44 & 49.01 & 37.37 & 48.8 & 48.03 & 30.69 & 45.98 & 34.87 \\
MUFA & 17.79 & 19.52 & 19.52 & 21.31 & 17.01 & 17.14 & 21.05 & 19.48 \\
PUFA & 42.12 & 30.02 & 32.2 & 28.81 & 32.14 & 42.52 & 30.33 & 42.66 \\
n3 PUFA & 31.79 & 23.46 & 26.92 & 16.5 & 22.54 & 34.49 & 19.24 & 30.57 \\
n6PUFA & 10.33 & 6.56 & 5.28 & 12.31 & 9.6 & 8.03 & 11.09 & 12.09 \\
n3/n6 & 3.08 & 3.58 & 5.10 & 1.34 & 2.35 & 4.29 & 1.73 & 2.53 \\
EPA/DHA & 1.49 & 1.74 & 2.02 & 4.08 & 1.35 & 1.62 & 1.51 & 1.55 \\
\hline
\end{tabular}

${ }^{\mathrm{a}} \mathrm{S}$. serrata, ${ }^{\mathrm{b}} \mathrm{S}$. tranquebarica, ${ }^{\mathrm{c}}$ Male body, ${ }^{\mathrm{d}}$ Male claw, ${ }^{\mathrm{e}} \mathrm{Female}$ body, ${ }_{\mathrm{f}}^{\mathrm{f}} \mathrm{Female}$ claw

et al., 2007). In the present study, n-3 to n-6 ratio ranged from 1.34 in claw meat to 5.10 in body meat of female $S$. serrata. Since FAO/WHO has recommended a dietary n-3 PUFA to n-6 PUFA ratio of at least 0.1-0.2 and considers higher ratios $(>0.2)$, more beneficial to human health (Wu et al., 2010), mud crab can be considered as a healthy seafood.

PCA was employed to explore the relationship among the different genders and body parts of the two species of mud crabs. A clear segregation in the data with respect to the n-3 PUFA content is visible from the PCA bi plot (Fig. 1). The n-3 PUFA content is found to be higher in the claw meat of $S$. tranquebarica and body meat of $S$. serrata irrespective of the gender, as explained by the PC1 representing $69 \%$ of the total variation in the data. PCA also revealed that the body meat of $S$. tranquebarica and claw meat of $S$. serrata are rich in saturated fatty acids, irrespective of the sex. The results indicate that variations in body parts, rather than the gender differences, play

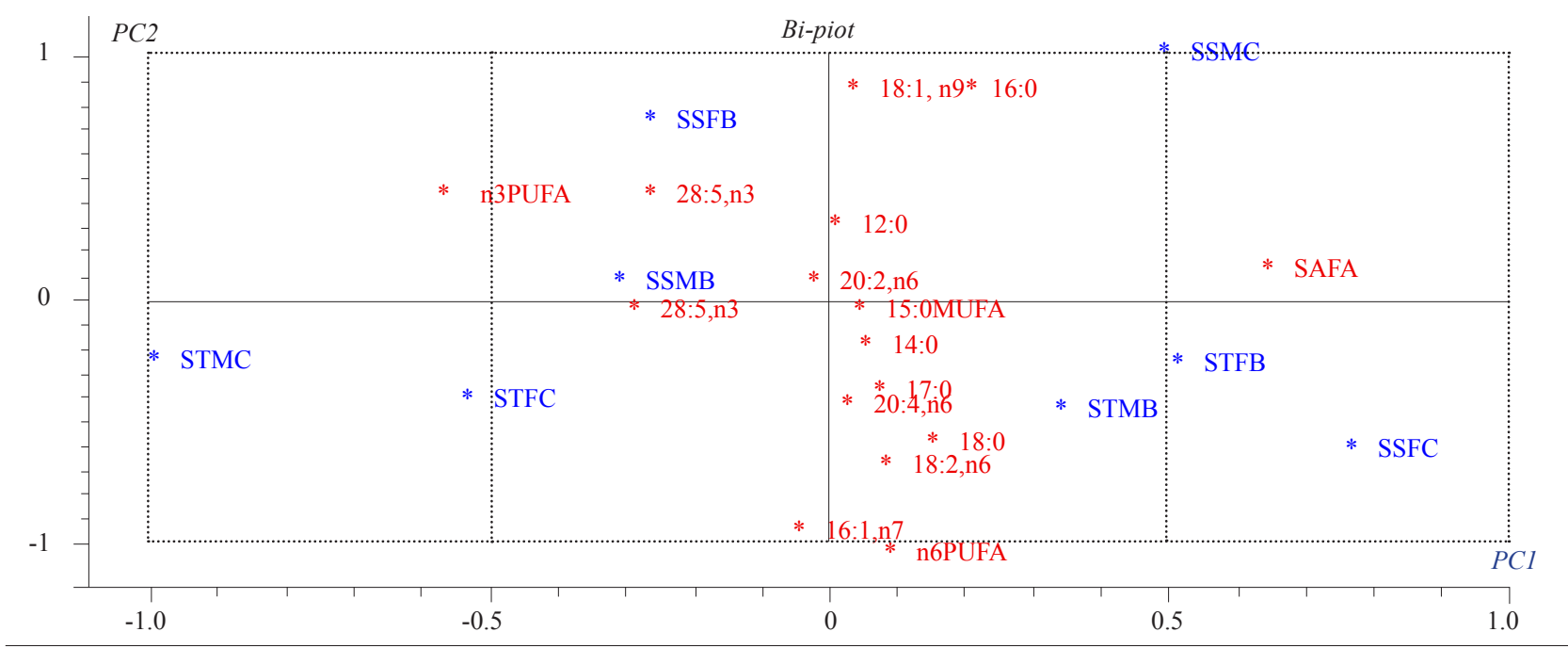

PCA FA groups, X-expl: $69 \%, 13 \%$

SS - Scylla serrata, ST - Scylla tranquebarica, MB - Male body, MC - Male claw, FB - Female body, FC - Female claw

Fig. 1. PCA bi plot representation of fatty acid composition of mud crab meat 
significant role in determining the fatty acid composition in mud crabs.

This study shows that there exists significant difference in the biochemical composition of mud crabs with respect to their species, gender and body parts. The higher ratio of n-3 to n-6 PUFA renders them the status of health beneficial and delicacy seafood.

\section{Acknowledgements}

Authors thank Dr. W. S. Lakra, former Director, ICAR-Central Institute of Fisheries Education, Mumbai for his help and support in carrying out this work.

\section{References}

AOAC 2000. Official methods for analysis, vol. 1, $17^{\text {th }}$ edn., Association of Official Analytical Chemists, Maryland, USA.

Balange, A. K., Vartak, V. R. and Singh, R. K. 2003. Mud crab Scylla tranquebarica (Fabricius) of west coast of India and its traditional culture practices in Konkan coastal region. Fishing Chimes, 23(1): 92-96.

Balasubramanian, C. P. and Suseelan, C. 2001. Biochemical composition of the deep-water crab Charybdis smithii. Indian J. Fish., 48(3): 333-335.

Barrento, S., Marques, A., Teixeira, B., Mendes, R., Bandarra, N., Vaz-Pires, P. and Nunes, M. L. 2010. Chemical composition, cholesterol, fatty acid and amino acid in two populations of brown crab Cancer pagurus: Ecological and human health implications. J. Food Compos. Anal., 23: 716-725.

Chen, D., Zhang, M. and Shrestha, S. 2007. Compositional characteristics and nutritional quality of Chinese mitten crab (Eriocheir sinensis). Food Chem., 103: 1343-1349.

Chinnamma, G. and Gopakumar, K. 1987. Biochemical studies on crab Scylla serrata (Forskal). Fish. Technol., 24: 57-61.

Chung, H. Y. 1999. Volatile components in crabmeats of Charybdis feriatus. J. Agr. Food Chem., 47(6): 2280-2287.

CMFRI 2011. Annual fish catch data.: http://www.cmfri.org.in/ annual-data.html. (Accessed 26 July 2013)
FAO. 2011. Global fishery production statistics.http://www.fao.org/ fishery/statistics/global-production/en. (Accessed 5 August 2013)

Folch, J., Lees, M. and Stanley, S. G. H. 1957. A simple method for the isolation and purification of total lipids from animal tissues. J. Biol. Chem., 226(1): 497-509.

Khan, P. A., 1992. Biochemical composition, minerals (calcium and iron) and chitin content of two portunid crabs Scylla serrata (Forskal) and Portunus pelagicus (Linnaeus) available in and around the coastal region of Bangladesh. M.Sc. Thesis, Institute of Marine Sciences, Chittagong University.

Latyshev, N. A., Kasyanov, S. P., Kharlamenko, V. I. and Svetashev, V. I. 2009. Lipids and fatty acids of edible crabs of north-western Pacific. Food Chem., 116: 657-661.

Lee, E., Meyers, S. P. and Godber, J. S. 1993. Minced meat crabcake from blue crab processing byproducts - Development and sensory evaluation. J. Food Sci., 58(1): 99-103.

Marques, A., Teixeira, B., Barrento, S., Anacleto, P., Carvalho, M. L. and Nunes, M. L. 2010. Chemical composition of Atlantic spider crab Maja brachydactyla: Human health implications. J. Food Compos. Anal., 23: 230-237.

Rattanachote, A. and Dangwatanakul, R. 1992. Report of seminar on the mud crab culture and trade held at Surat Thani, Thailand, November 5-8, 1991. Bay of Bengal program, BOBP/Rep/51, Madras, India, 171-177p.

Wu, X., Zhou, B., Cheng, Y., Zeng, C., Wang, C. and Feng, L. 2010. Comparison of gender differences in biochemical composition and nutritional value of various edible parts of the blue swimmer crab. J. Food Comp. Anal, 23: $154-159$

Zafar, M., Siddiqui, M. Z. H. and Hoque, M. A. 2004. Biochemical composition in Scylla serrata (Forskal) of Chakaria Sundarban Area, Bangladesh. Pak. J. Biol. Sci., 7(12): 2182-2186. 